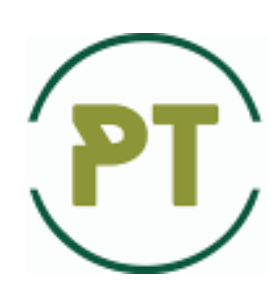

Problems of Tribology, V. 26, No 1/99-2021,74-83

Problems of Tribology

Website: http://tribology.khnu.km.ua/index.php/ProbTrib

E-mail: tribosenator@gmail.com

DOI: https://doi.org/10.31891/2079-1372-2021-99-1-74-83

\title{
Study influence factors of the spraying process on the properties of electric arc spraying coatings
}

\author{
M. Ageev ${ }^{1 *}$, E. Solovuch ${ }^{2}$, V. Lopata ${ }^{3}$, O. Burlachenko ${ }^{3}$, N. Vihilianska ${ }^{3}$ \\ ${ }^{I}$ Kherson State Maritime Academy, Ship Power Plant Operation, c. Kherson, Ukraine \\ ${ }^{2}$ Central Ukrainian National Technical University National technical, Kropynnytskyi, Ukrain \\ ${ }^{2}$ E.O. Paton Electric Welding Institute of the National Academy of Sciences of Ukraine
}

*E-mail: beryuza@ukr.net

\begin{abstract}
The paper considers possibilities to increase the wear resistance, corrosion resistance, and service life for parts machines and mechanisms via their hardening and renovating using electric arc coatings characterized by high density, adhesion strength, and micro hardness thanks to activation of the spraying process. Also, the possibility of controlling the properties of restored surfaces owing to choice of the related equipment with required structure and characteristics in order to prolong the service life of machinery parts is shown. The right choice of equipment for spraying makes it possible to increase the speed and temperature of the spraying gas and particles, reduce the droplet diameter, increase the density and reduce the oxidation of coatings.

The influence of spray factors such as the flow rate and pressure of working gases, composition of combustion mixture, spraying distance, dispersion of the spray, properties of wire material, etc. on the properties of the coatings obtained has been investigated. The possibility of controlling the properties of surfaces owing to choice with required characteristics electric arc coatings is shown. The influence of spray factors such as the flow rate and pressure of working gases, composition of combustion mixture, spraying distance, dispersion of the spray, properties of wire material, etc. on the properties of the coatings obtained has been investigated.

The use of coatings makes it possible to increase the wear and corrosion resistance of working surfaces of machine parts and mechanisms, in particular ship parts, and so to reduce the costs of alloyed steels and alloys. The coatings application is associated with implementation of a fundamentally new approach, according to which the strength and carrying capacity of a part is provided by its basic material, whereas the resistance to corrosion, wear, and other factors may be increased via using hardening protective coatings. There are many alternative methods for producing coatings, from which it is advisable to choose an optimal, easy to implement, and inexpensive one.

Of the variety of methods for hardening coating deposition, the most common technologies used to restore and improve the performance properties of parts are gas-thermal spraying techniques, among which the cheapest and simplest method is electric arc spraying (EAS), whose current improvement is aimed at modifying and activating the spraying process. Such combined technologies do not require additional expensive equipment and operations, which predetermines a reduction in the cost of hardening processes.
\end{abstract} process

Key words: electric arc coating, wear resistance, corrosion resistance, adhesion strength, spraying

\section{Introduction. The state of the problem and the purpose of the research.}

In the practice of restoring and hardening parts through the use of hardening protective coatings, extensive experience has been accumulated in the application of coatings by methods of gas-thermal spraying (GTS) [1-3]. The reasonability of using GTS is evidenced by the appearance of a number of special firms for manufacture of equipment and materials for spraying, for example, Metko, Wall Cobmonoy Corp. Linde Div., Union Carbide Corp. et al. [4-7]. The produced domestic and foreign GTS units [8], spray materials [6-10], and published recommendations have made it possible to solve a series of items related to the repair, restoration, and prolongation of the service life of parts [1-3].

Copyright (c) 2021 M. Ageev, E. Solovuch, V. Lopata, O. Burlachenko, N. Vihilianska. This is an open access article distributed under the Creative Commons Attribution License, which permits unrestricted use, distribution, and reproduction in any medium, provided the original work is properly cited. 
In the development of techniques for restoration of parts, it is necessary, of all the possible GTS methods (Table 1) [4-6], to choose such one that provides the longest service life of a part and the lowest cost of its recovery as well as can be fairly versatile, simple, and easy to implement [8].

When choosing a method for GTS, it is necessary to consider the basic conditions for high-quality coating formation [4]: i) thermal effects on the part must prevent the phase or structural transformations in the base metal; ii) participation of the base metal in the coating must be negligible, and iii) in the contact zone, no relaxation process capable to change its phase composition and structure should arise.

Table 1

\section{Characteristics of spraying modes}

\begin{tabular}{|l|c|c|c|c|}
\hline \multirow{2}{*}{ Parameter } & \multicolumn{4}{|c|}{ Spraying mode } \\
\cline { 2 - 5 } & Electric arc & Gas-flame & Plasma & Detonation \\
\hline Efficiency, kg/h & $3-31$ & $1-10$ & $0.5-8.0$ & $0.1-6.0$ \\
\hline Coefficient of material & $0.8-0.9$ & $0.8-0.95$ & $0.4-0.9$ & $0.3-0.6$ \\
\hline Adhesion strength, MPa & to 40 & to 50 & to 60 & to 200 \\
\hline Temperature of part heating,${ }^{\circ} \mathrm{C}$ & $100-150$ & $100-150$ & $150-200$ & $100-150$ \\
\hline
\end{tabular}

From the standpoint of these conditions, the use of electric arc spraying (EAS) is promising [9, 10]. EAS is widely used in the European countries and displaces the traditional gas-flame method [7]. This is due to the simplicity of the equipment, the availability of energy source for metal melting, higher thermal efficiency, which reaches $57 \%$ compared to 13 and $17 \%$ for gas and flame spraying $[9,10]$.

Despite the large number of innovations concerning electric arc spraying (EAS), researches on the improvement of this method and required equipment are actively being carried out and has become aimed at activating the spray process using various techniques, methods, and devices [11-13]. The spray process activation is the basis for improving the technology and equipment for deposition of high-density wear-resistant layers. In practice, the following procedures for spray process activation have been implemented [11-13]:

- intensification of mixing working gases;

- provision of sprayed particles and the substrate with additional energy via heating them;

- diminution of the sprayed particles size;

- activation of the particle and the substrate surfaces by mechanical methods (increase in roughness) or by reduction of oxides;

- increase in the enthalpy of the spray flux by introducing thermo-reactive components;

- coating with the use of external effects (ultrasonic waves, electromagnetic fields, etc. [14];

- heat treatment $[15,16]$ or chemical heat treatment of coatings $[17,18]$, etc.

On the basis of studying the problem of hardening and restoring parts of the using electric arc spraying (EAS) coatings, the aim of the work was set up to increase the wear resistance and service life of parts via combining electric arc spraying (EAS) coatings characterized by high density, adhesion strength, and microhardness due to the activation of the spray process and nitriding of the coatings sprayed.

The influence of choice of design parameters for of electric arc spraying equipment on the factors of spray process and properties of coatings

The quality of electric arc spraying (EAS) coatings used for renovation and hardening of the working surfaces of parts markedly depend on the technical characteristics of the equipment used.

Currently, there is in operation a wide range of power sources and devices for spraying produced by various companies [19-22]. However, a comparative analysis of the influence of the main technical characteristics of spray units and power sources on the physicomechanical properties of the coatings obtained has not been carried out; and no science-based recommendations on the use of electric arc spraying (EAS) equipment have been made. The above reasons make it difficult to choose the right equipment for electric arc spraying (EAS) that could provide high performance and quality of the recovered parts. This paper presents the characteristics of the most used units and analysis of them in order to ensure their correct choice. The characteristics of the power source and the design of an apparatus for an electric arc determine such electric arc spraying (EAS) factors as the welding current; the type, pressure, and flow rate of the spraying gas; the diameter and shape of the nozzle, and the scheme of a blowing system. To create electric arc spraying (EAS) coatings, units with various blowing systems and nozzle geometry are used [23, 24]. Currently, there are several schemes for the formation of the metal-air flow for electric arc spraying (EAS), namely diaphragm, central-nozzle, differential, and closed ones. In particular, the most widespread diaphragm scheme is used in the manufacture of electric arc spraying (EAS) units at the Barnaul plant (Russia) and firms "Metco" and "Mogul" (the United States). For this scheme, formation of a fairly wide metal-air flow is characteristic. The use of it is effective for obtaining anti-corrosion coatings. The central nozzle scheme is used in the electric arc apparatus EM-17 (Barnaul), where a narrow metal-air flow is created, which is particularly efficient for coating of bodies of revolution, for example shafts, including crankshafts [23, 24]. 
At the Physical-Mechanical Institute (PMI) of NAS of Ukraine (Lviv), through improving the design of electric arc spraying (EAS) equipment and increasing the protective-energy level of the spray arc flame, the problem of increasing the physicomechanical properties of coatings was solved by weakening the dispersed metal oxidation in the spray flame and increasing the velocity of particles $[23,24]$. In order to improve the quality of coatings, an electric arc apparatus with a spray head was used [23,24], which was based on a closed scheme for the formation of metal-air flow. Such a scheme is used in the units manufactured by the GMP "Gasothermic" at PMI of NAS of Ukraine. The advantages of EM-14 units with a closed scheme and a differential nozzle over an open scheme and a central nozzle are considered in [24]. The closed scheme of metalair flow formation allows the manufacture of extremely fine fractions of sprayed particles (below $50 \mu \mathrm{m}$ ) thanks to their high flight velocity $(50-130 \mathrm{~m} / \mathrm{s})$ from the burning arc zone to the surface being restored (Fig. 1, a, b). Such a spray scheme should be used when the need arises in fine-particle $(50-200 \mu \mathrm{m})$ coatings via spraying wires that include refractory components. If the metal-air flow scheme is closed, the arc burns in a channel bounded with the spray head of the electric arc spraying (EAS) apparatus. This scheme realizes its advantages when the arc cross section size becomes commensurate with the cross section of the cylindrical channel where it burns. The closed metal-air flow scheme allows two deposition modes: continuous and pulsed. Upon reducing the diameter of the nozzle cylindrical part, the pressure in the nozzle may become equal to that in the arc gap. With this, cold air may actively penetrate into the arc burning zone and so help decrease its length. When the arc length decreases so much that the melt can close the arc gap, a pulsed mode is realized. The pressure in the arc markedly depends on the nozzle diameter and arc power.

It was established experimentally that the larger the nozzle diameter, the greater the arc power should be in order to realize the pulsed mode of the electric arc apparatus operation. When the pulverization apparatus is in the pulsed mode, the wire tips become parallel. The liquid phase closes the tips, and the reycotron effect is realized, which is manifested in the fact that an electrodynamic force acts parallel to the surfaces of wires, which melt in the gaps between the two parallel wires-electrodes. The melt is ejected from the gap by electrodynamic forces, and after a pause the cycle repeats. The frequency of emissions depends on the wire feed speed. Portions of the liquid metal receive an additional impulse owing to the reycotron effect, which increases the velocity of particles and contributes to the melt dispersion.

The use of the closed scheme for the formation of metal-air flow during EAS [23, 24] allows production of coatings with a density of over $90 \%$ and adhesion strength to $180 \mathrm{MPa}$. The maximum size of sprayed particles does not exceed $50 \mu \mathrm{m}$. Thus, the EM-14 spraying system (Fig. 1, c), which provides arc burning in a channel bounded with the nozzle walls or in the formed flow of pressing air, makes it possible to produce droplets with a high flight velocity, which improves the properties of the surfaces being restored.

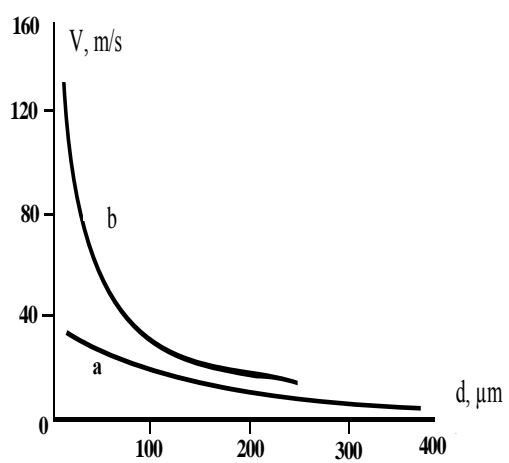

$\mathrm{a}, \mathrm{b})$

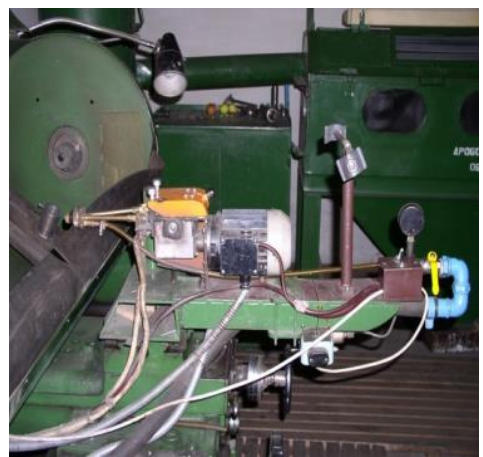

c)

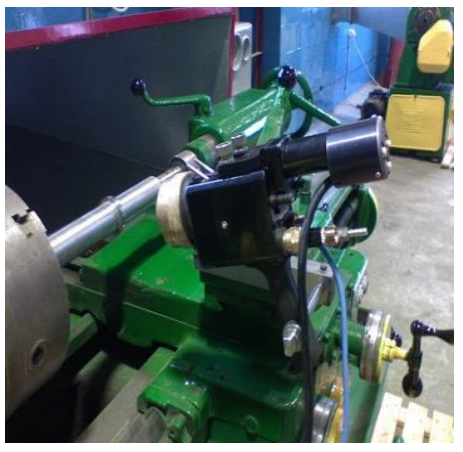

d)

Fig. 1. Dependence of the velocity of metal particles on their size for different modes of metal-air flow formation (a, b): central nozzle scheme (a) and closed scheme (b); apparatus EM-14 for electric arc spraying (c); d) unit for electric arc spraying (EAS) with a propane-air combustion chamber

In the apparatus EDM-6GD designed by the Mariupil State University and the company TOPAZ, spraying is performed with gas-dynamic dispersion of metal and using an external chamberless combustion scheme. Here the energy source (electric arc and compressed air) is replaced by an electric arc and a fast jet of the products of liquid hydrocarbon fuel combustion [25]. This design allows reduction in the oxidation potential of the medium compared to air by twice and improvement in the properties of surfaces restored. The adhesion strength of coatings increases by $56 \%$ and hardness by $18 \%$, while the porosity of coatings decreases by 2.6 times. At the same time, the cost of the electric arc spraying (EAS) process decreases thanks to the replacement of cored wires with 2-3 times cheaper standard solid-drawn ones.

The units for electric arc spraying (EAS) produced by NPOOO "MAD" (Minsk) combine the advantages of electric arc and fast spraying [19-22] (Fig. 1, d). The main distinguishing feature of the electric arc spraying (EAS) unit is the presence of an efficient small-sized chamber for propane/air mixture combustion. A fast jet of 
the combustion products leaves it with a speed of $1500 \mathrm{~m} / \mathrm{s}$ at the outlet. The unit operates on the basis of melting wires by an electric arc and spraying molten wire droplets with the fast jet of combustion products. It requires supply of compressed air with pressure from 0.6 to $0.8 \mathrm{MPa}$ and propane with pressure from 0.3 to 0.45 $\mathrm{MPa}$ as well as a source of welding current with a "hard" voltage-current characteristic (of the "VDU-506" type). By varying the consumption of propane and air, it is possible to create a neutral or reducing atmosphere in the melting zone of the electrode wire and thereby to weaken metal oxidation and burnout of alloying elements [19-22]. Moreover, the design features of such units make it possible to increase the velocity of sprayed material particles and the coefficient of material utilization to 0.85 ; herein the jet angle does not exceed $10^{\circ}$. The EAS- 10 unit has an electric drive which provides the required speed of wire electrode feed. It is powered from a threephase network of $220 \mathrm{~V}$, frequency $50 \mathrm{~Hz}$ [22]. In the case of using an alternating current, the electric arc burning proceeds with periodic interruptions that occur as a result of the voltage drop. The power supply for the electric arc apparatus with a direct current forms the necessary conditions for obtaining coatings with a uniform thickness. Analysis of the research results made it possible to recommend the EM-14 apparatus (Fig. 1, c) and the EAS-10 unit (Fig. 1, d) for deposition of EAS coatings. The proper management of the design parameters of equipment for electric arc spraying (EAS) provides the creation of coatings with high performance characteristics, which is very important for increasing the service life of parts. Thus, the work shows the possibility, through the selection of design parameters and characteristics of equipment for electric arc spraying (EAS), to control the properties of coated surfaces in order to increase the service life of restored parts. The right choice of equipment for electric arc spraying (EAS) allows one to increase the speed and temperature of the jet of spraying gas and particles, decrease the size of droplets, increase the density and reduce the oxidation of coatings. Additionally, it has made it possible to use standard solid-drawn wires from martensitic steels $40 \mathrm{Kh} 13$ and $95 \mathrm{Kh} 18$ and austenitic steels Kh18N10T and 12Kh18N10T instead of more expensive cored wire FMI.

Study influence factors of the spraying process on the properties of electric arc spraying coatings. Control of structure formation processes in sprayed coatings

A distinct feature of the martensitic and austenitic steels is the ability for phase transformations and structural changes during deposition and processing of coatings, which results in improving the physicomechanical and operational properties of hardened surfaces. The process of restoration of surfaces via electric arc spraying (EAS) coating is divided into three main stages: surface preparation, coating, and subsequent treatment of the surface coated. Studies of the effect of the average particle size of spray wires from $20 \mathrm{Kh} 13,12 \mathrm{Kh} 18 \mathrm{~N} 10 \mathrm{~T}$, and nichrome on the physicomechanical properties of coatings revealed that coatings made from steel wires show a decrease in adhesion with increasing porosity, whereas nichrome does not obey this rule. Comparative tribological tests were conducted for coatings from steel 40Kh13. For comparison, samples from rolled steel $40 \mathrm{Kh} 13$, which was pre-quenched and tempered at $970 \mathrm{~K}$ for $5 \mathrm{~h}\left(H_{v}=27 \mathrm{GPa}\right)$, were tested as well. Under friction without lubrication, an adhesion interaction of the coating material with the counterbody occurs, accompanied by a tear and intense weight wear of the coupling materials (Fig. 2).

As seen in the figure, the curve of accumulated weight wear of tempered steel has a characteristic stage of running-in and a steady wear stage with almost linear dependence of the weight wear on the friction path. For electric arc spraying (EAS) coatings, the stages of steady wear periodically alternate with the relatively shortterm stages of accelerated wear, i.e., wear of electric arc spraying (EAS) coatings is pronouncedly cyclical (Fig. 2). The highest averaged weight wear rate was $0.41 \mathrm{mg} / \mathrm{m}$ (Table 2 ).

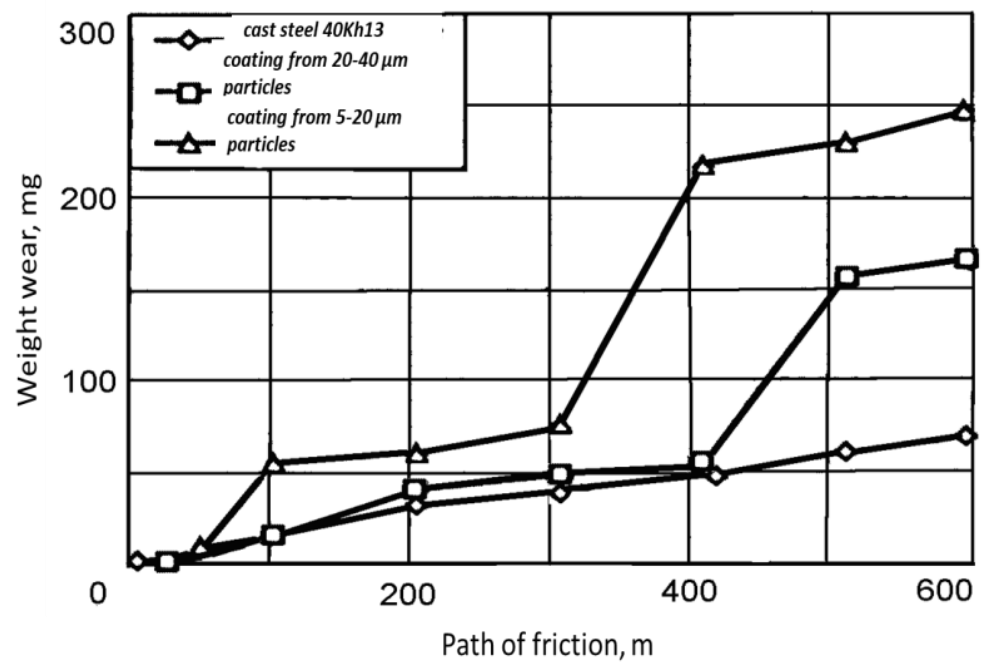

Fig. 2. Dependence of the weight wear on the friction path for electric arc spraying coatings from steel $40 \mathrm{Kh} 13$ (friction without lubrication, pressure 1.5 MPa, counterbody from hardened steel 60) 
Wear rate and coefficient of dry friction for electric arc spraying coatings

Table 2. and tempered cast steel $40 \mathrm{Kh} 13$

\begin{tabular}{|c|c|c|}
\hline Material & Wear rate, $\mathrm{mg} / \mathrm{m}$ & Coefficient of friction \\
\hline Cast steel 40Kh13 & 0.11 & $0.80-0.92$ \\
\hline EAS coating & 0.28 & $0.85-0.95$ \\
\hline EAS coating & 0.41 & $0.95-1.05$ \\
\hline
\end{tabular}

A number of researchers have noted that the structure of coatings obtained by spraying the same wire material by different modes can differ not only in the number of pores, but also in the phase composition [19-21, 26-29]. This paper presents the results of studies of the structural features of electric arc spraying (EAS) coatings. As spray materials, $40 \mathrm{Kh} 13$ wires with a diameter of $2 \mathrm{~mm}$ were used. Spraying was performed using an apparatus for electric arc spraying (EAS) in the following modes:

- mode 1: spaying of metal melted in an electric arc with a reactive jet of combustion products of propane/air mixture with an excess of propane (reducing atmosphere);

- mode 2: spraying of metal melted in an electric arc with a reactive jet of combustion products of the propane/air mixture with an excess of air (oxidizing atmosphere);

- mode 3: spraying of metal melted in an electric arc with a fast air jet.

To improve the adhesion of coatings to a steel 3 substrate, an intermediate layer from alloy Kh20N80 was created. The velocity of molten particles was $120-130 \mathrm{~m} / \mathrm{s}$ (modes 1 and 3 ) and $400-500 \mathrm{~m} / \mathrm{s}$ (modes 1 and 2). The sizes of the particles from which the coatings were formed fell in the range of 5-40 $\mu \mathrm{m}$. The dominant amount of oxides was formed as a result of the molten particles/air contact. In the work, the effect of the spraying air flow rate on the amount of oxygen in the coatings obtained by electric arc spraying (mode 3 ) was studied (Fig. 3). Here the oxygen content in electric arc spraying (EAS) coatings was 2.5-3 times that in gasflame ones (Fig. 4), with achieving the maximum concentration $3.8 \%$ at flow rates of about $0.5 \mathrm{~m}^{3} / \mathrm{min}$.

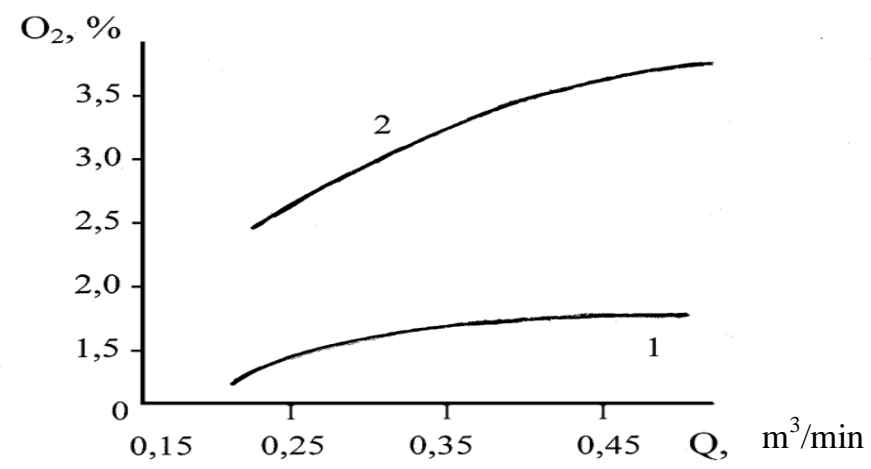

Fig. 3. Influence of the flow rate of spraying air on the oxygen content in coatings obtained by (1) mode 2 and (2) mode 3.

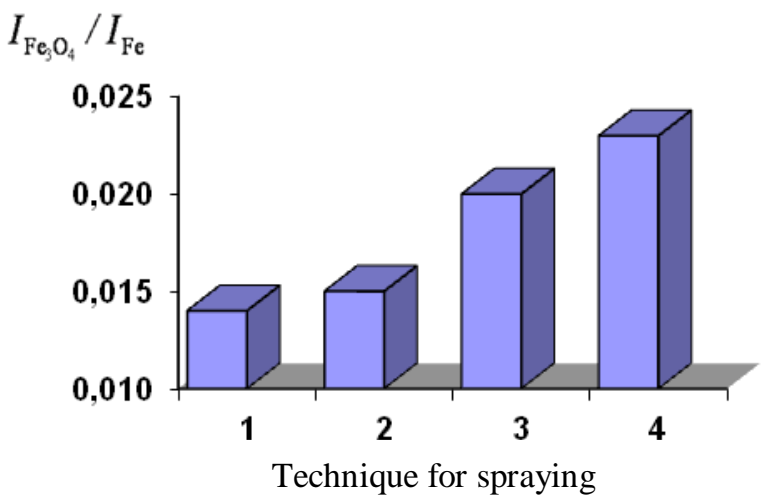

Fig. 4. The relative content of $\mathrm{Fe}_{3} \mathrm{O}_{4}$ in coatings obtained using: (1) gas flame; (2) activated $\mathrm{EAS}$ in a reducing atmosphere; (3) activated EAS in an oxidizing atmosphere; (4) spraying with air. 
An XRD analysis (diffract meter DRON-3.0, monochromatic CoK $\alpha$ radiation, $\mathrm{V}=30 \mathrm{kV}, \mathrm{I}=10 \mathrm{~mA}$ ) revealed that the phase composition of the coatings includes: $\alpha$-phase (martensite), $\gamma$-phase (austenite), oxides $\mathrm{Fe} 3 \mathrm{O} 4, \gamma$-Fe2O3 (traces), and $\mathrm{Cr} 2 \mathrm{O} 3$ (traces) (Fig. 5). The hardness of the coatings obtained using various spray schemes was within the HV range of 2800 - $3500 \mathrm{MPa}$.

Activation of electric arc spraying (AEAS) in a reducing atmosphere leads to the formation of dense coatings with a porosity of $2-5 \%$ and hardness $\mathrm{HV}=3000 \mathrm{MPa}$, characterized by low content of residual austenite $(\mathrm{V} \gamma \approx 20 \mathrm{vol} \%)$ and oxides. The lattice parameters of martensite and austenite are a $\alpha=0.2875 \mathrm{~nm}$ and $\mathrm{a} \gamma=0.3592 \mathrm{~nm}$, respectively.

Activation of electric arc spraying by a reactive jet with an excess of air provides the formation of a layer with a porosity of $2-5 \%$ and hardness $\mathrm{HV}=3500 \mathrm{MPa}$, characterized by substantial content of oxidation products. The content of residual austenite in the coating is $\mathrm{V} \gamma \approx 20 \mathrm{vol} \%$. The lattice parameters of martensite and austenite are $a \alpha=0.2875 \mathrm{~nm}$ and $\mathrm{a} \gamma=0.3592 \mathrm{~nm}$, respectively.

Coatings obtained by spraying with air had a hardness of $\mathrm{HV}=3200 \mathrm{MPa}$ and a residual austenite content of $\mathrm{V} \gamma \approx 18 \mathrm{vol} \%$ at the porosity $6-8 \%$. The XRD data fixed the highest concentration of oxidation products in the coating after electric arc spraying (EAS) with air. Lattice parameters were $a \alpha=0.2875 \mathrm{~nm}$ and $\mathrm{a} \gamma=0.3596 \mathrm{~nm}$ for martensite and austenite, respectively.

The results of the study of the phase composition and hardness of coatings from steel $40 \mathrm{Kh} 13$ indicate the influence of the deposition technique on the structure and properties of the layer obtained. A distinctive feature of deposited layers is the presence of an anomalously large amount of residual austenite (up to 30 vol\%) and oxides. Generally, the content of residual austenite in hardened steel $40 \mathrm{Kh} 13$ does not exceed 3 - 5 vol\% [2629].

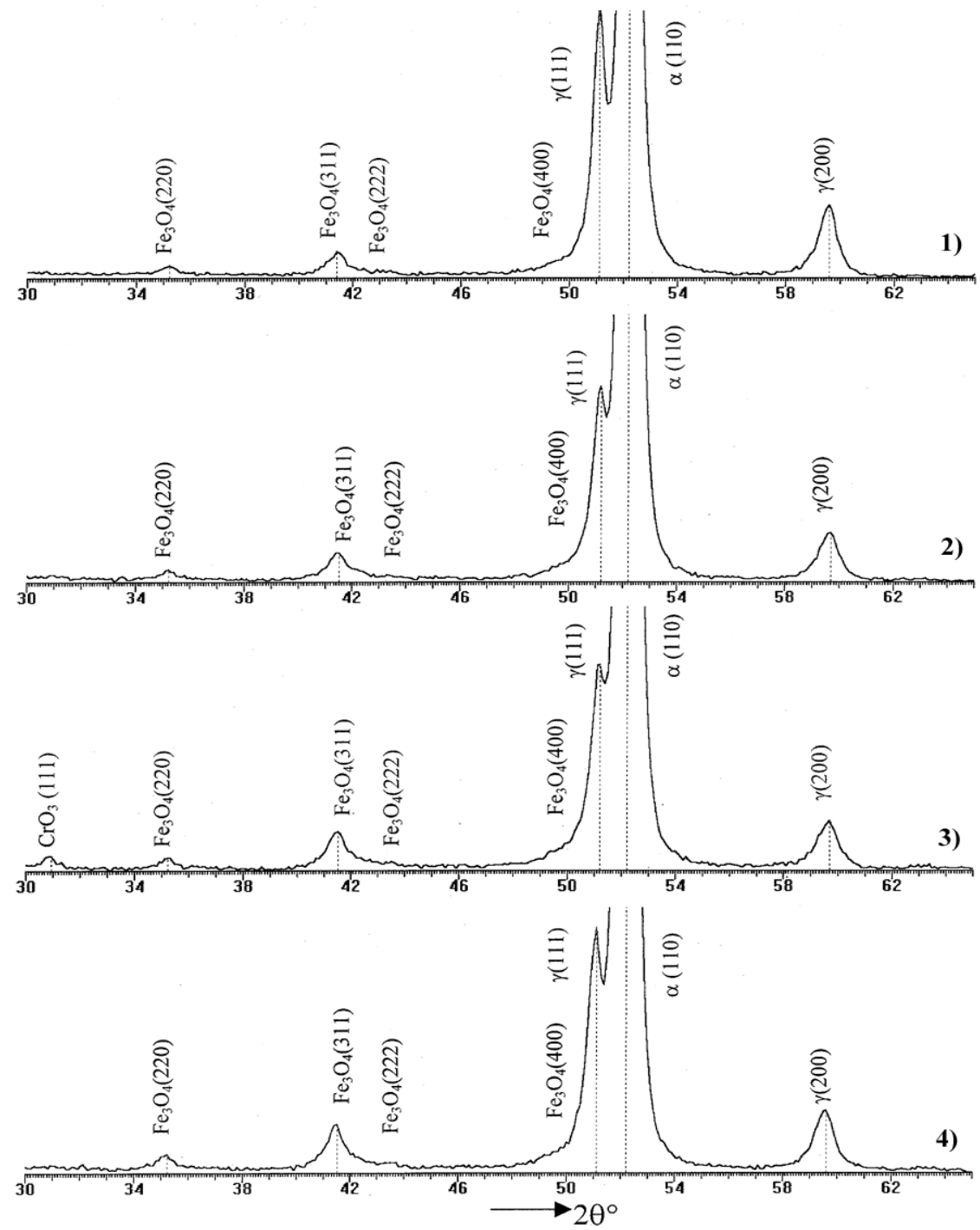

Fig. 5. Fragments of XRD patterns $(\mathrm{CoK} \alpha)$ from surface layers of gas-thermal coatings obtained under modes 1-4.

One of the reasons for the appearance of the "austenitic effect" in coatings is a higher concentration of alloying elements (chromium and carbon) owing to the complete dissolution of chromium carbides during 
melting of the wire and saturation of the molten droplets with carbon from the propane flame. This is confirmed by the absence of $\mathrm{Cr} 23 \mathrm{C} 6$ carbide particles in the coating. While analyzing the causes of austenite stabilization in the layer, one should keep in mind that under spraying surface layers are heated to 500-670 K. As a result, the sprayed coating undergoes isothermal aging at 520-670 K during its formation and cooling, which promotes thermal stabilization of austenite [26-29]. A factor that increases the stability of austenite in the sprayed layers is saturation of the molten droplets with carbon during melting and spraying with propane flame (Table 3 ).

The low velocity of molten steel particles and high concentration of carbon-containing propane in the combustion products contribute to a deeper saturation of molten droplets with carbon.

These circumstances are associated with a high content of residual austenite in coatings obtained by the gas flame procedure (technique 1).

The smaller amount of austenite in coatings obtained by activation of electric arc spraying (AEAS) in the reducing atmosphere of the spray torch (technique 2) is due to the higher flight velocity of the molten particles, which is characteristic for this technique.

In this case, the processes of diffusion saturation of the droplets with carbon from the reducing atmosphere of the products of propane/air mixture combustion do not have enough time to complete (flight time of molten droplets in the atmosphere of combustion products is not more than $510^{-4} \mathrm{~s}$ ), and the content of residual austenite in the layer decreases to $\sim 20 \mathrm{vol} \%$. An increase in the oxygen concentration in the mixture is not accompanied by change in the amount of residual austenite in the coating obtained under conditions of supersonic velocities of molten particles (technique 3) and at relatively low particle velocities (technique 4). In both cases, the content of residual austenite in the layer does not exceed $20 \mathrm{vol} \%$.

The carried-out studies made it possible to conclude that for electric arc spraying (EAS) there are such regimes and steels that can provide the formation of a large amount of metastable austenite in the coatings, which during the performance of the tribocoupling will turn into martensite.

Table 3

The influence of the composition of combustion mixture forming the spray on the carbon and oxygen contents in electric arc spraying (EAS) coatings from steel 40Kh13

\begin{tabular}{|c|c|c|c|}
\hline $\begin{array}{c}\text { Technique } \\
\text { of spraying }\end{array}$ & $\begin{array}{c}\text { Air/propane volume ratio } \\
\text { in mixture }\end{array}$ & $\begin{array}{c}\text { Oxygen content in } \\
\text { coatings, } \%\end{array}$ & $\begin{array}{c}\text { Carbon content in } \\
\text { coatings, } \%\end{array}$ \\
\hline 1 & (Gas flame) propane/oxygen ratio 1/4 & 1.3 & 0.6 \\
\hline 2 & Activation of electric arc spraying (AEAS) 18 & 1.4 & 0.5 \\
\hline 3 & Activation of electric arc spraying (AEAS) 30 & 2.2 & 0.4 \\
\hline 4 & Activation of electric arc spraying (AEAS) clean air & $3.3-3.5$ & 0.4 \\
\hline
\end{tabular}

The experiments established a relation between the temperature of the beginning of martensitic transformation, $T_{M}$, for the wire material and the amount of metastable austenite formed in the resultant coating (Table 4) [26-29].

In steels of group 1, as well as in corrosion-resistant martensitic steels, the temperature $T_{M}$ is within 550 $700 \mathrm{~K}$. When spraying wires from these steels, the volume content of metastable austenite reaches $45 \%$.

Table 4

Metastable austenite content in electric arc spraying (EAS) coatings obtained by spraying various steel grades

\begin{tabular}{|c|c|c|c|c|}
\hline $\begin{array}{l}\text { Group } \\
\text { of steels }\end{array}$ & Steel grade & Temperature, $T_{M}, \mathrm{~K}$ & $\begin{array}{l}\text { Temperature of heating } \\
\text { under spraying, } K\end{array}$ & $\begin{array}{l}\text { Content of austenite in } \\
\text { coating, vol } \%\end{array}$ \\
\hline 1 & $\begin{array}{c}\text { 09G2S, 40KhN, } \\
\text { 20Kh13, 40Kh13 }\end{array}$ & $550-700$ & $\begin{array}{c}1700-2000 \\
2100-2500 \\
>2600\end{array}$ & $\begin{array}{c}25-45 \\
17-20 \\
<6\end{array}$ \\
\hline 2 & $\begin{array}{c}\text { 9KhS, Kh12MF, } \\
\text { 9Kh12, Kh6VF, } \\
\text { 35KhNM, } \\
\text { 40KhFVA, 65G }\end{array}$ & $420-540$ & $\begin{array}{l}1700-2100 \\
2200-2500 \\
>2500\end{array}$ & $\begin{array}{c}15-25 \\
8-12 \\
<6\end{array}$ \\
\hline 3 & $\begin{array}{l}\text { 08Kh18N10, } \\
\text { 12Kh18N10T, } \\
110 \mathrm{G} 13\end{array}$ & $70-110$ & $\begin{array}{c}1700-2000 \\
2000-2500 \\
>2500\end{array}$ & $\begin{array}{l}95-98 \\
90-95 \\
90-95\end{array}$ \\
\hline
\end{tabular}

In the case of spraying wires from steels of the first two groups, the preservation of a large amount of metastable austenite can be prescribed to the high rate of crystallization of steel particles in the course of forming the sprayed layer and slowing down its cooling rate in the martensitic transformation region. The decrease in austenite stability in coatings from steels of the third group, sprayed over $2500 \mathrm{~K}$, is explained by the effect of 
manganese and chromium contained in the steel on the temperature range of its martensitic transformation. Thus, a decrease in the manganese content from 5\% to $1 \%$ leads to an increase in the temperature from 270 to $470 \mathrm{~K}$ [26-29]. In this regard, one of the possible ways to increase the $T_{M}$ temperature is reduction in the chromium or manganese content in the austenitic phase of steels by oxidizing it during spraying.

\section{Conclusions}

The present work recommends to increase the wear resistance, corrosion resistance, and service life of SMM parts via hardening and renovating them using combined electric arc spraying EAS coatings characterized by high density, adhesion strength, and microhardness due to activation of the spraying process and subsequent nitriding of the coatings sprayed.

It has been shown that by properly choosing design parameters and characteristics of equipment for electric arc spraying EAS, it is possible to control the properties of restored surfaces in order to increase the service life of parts. The right choice of equipment for spraying will allow one to increase the speed and temperature of the jet of spraying gas and molten particles, decrease the droplet diameter, increase the density, and reduce the oxidation of coatings.

Moreover, the phase composition and microhardness of coatings obtained by spraying wires from austenitic and martensitic steel were investigated. The presence of an abnormally large amount of residual austenite (to $50 \mathrm{vol} \%$ ) in coatings from martensitic steel was established.

Studies of the resistance to fatigue failure showed that coatings deposited by electric arc spraying (EAS) of wires provide a slight decrease in the fatigue strength limit to $10-13 \%$ (for comparison, coatings obtained by vibro-arc surfacing reduce the fatigue limit by $35-40 \%$ ).

In the course of tribological tests, the wear of sprayed coatings was established to be cyclical. The cyclicity of weight wear of sprayed coatings is associated with the degradation of their surface layer under friction, described in terms of physical mesomechanics of solids.

\section{References}

1. Ageev M.S. Protective and hardening coatings in ship building and repair / Ageev M.S, Volkov Yu.V., Chigrai S.L. // Bulletin KhDMA - Kherson:. 2 (13). 2015. P.110-124.

2. Ageev M.S. Welding and related processes in ship building / Ageev M.S., Volkov Yu.V., Chigray S.L. // "Water Transport” Kyiv, №2 (24), , 2015. P. 15-26.

3. Kornev A. Development of strategy for repair of tribocouplings of large-sized parts using gas-thermal spraying in ship repair: Thesis. N. Novgorod, 2006. $-23 \mathrm{p}$.

4. Iliuschenko A.F. Formation of gas-thermal coatings: theory and practice / Iliuschenko A.F. Okovity V.A., Kundas S.P., Formanek B. - Minsk, 2002.

5. Theory and practice of gas-thermal spraying / Vitiaz P.A., Ivashko V.S., Manoilo E.D. and others. Minsk: Science and Technology, 1993. - 295 p.

6. Gas-thermal spraying / L.Kh. Baldaev et al. - Market DS, 2007. 344 p.

7. Kharlamov Yu.A. Thermal spraying of coatings and ecological compatibility of production, operation and repair of machines / Yu.A. Kharlamov // Heavy engineering- №2. 2000 - P. 3-10.

8. Kondratiev V.A., Kondratiev M.V. Choosing a rational recovery method. Innovative technologies and equipment of the machine-building complex: Coll. scientific works. Issue 4. Voronezh: 2005, P. 35-38.

9. Boronenkov V.N., Korobov Yu.S. Fundamentals of arc metallization. Physicochemical regulairities. USU; Yekaterinburg: Univ. Publ. house 2012, 267 p.

10. Zagorsky Ya.V. The mechanism of electric arc hardening of low- and medium-carbon steels. Congress materials. Ufa: Mir pechati, 2003, 105 p.

11. Korobov Yu.S. Efficiency of using activated arc coating metallization / Yu.S. Korobov // Welding Production., No. 2. 2005. P. 47-50, 62, 64.

12. Priadko A.S., Korobov, Yu.S., Lukanin V.L. Activated arc metallization: the characteristics of the equipment and its application // Films and Coatings 98: Proc. $5^{\text {th }}$ Inter. conf. Saint-Pb. 1998. P. 249-251.

13. Belotserkovsky M.A. Technological features and areas of using hypersonic metallization / M.A. Belotserkovsky, A.S. Pryadko, A.E. Cherepko // Innovations in mechanical engineering: Coll. of papers. Minsk, OIM NAS Belarus. 2008. -P. 479 - 484.

14. Vitiaz P.A., Azizov R.O., Belotserkovsky M.A. Hardening of gas-thermal coatings. - Minsk: Bestprint, 2004. - 192 p.

15. Glebova M.A., Kornev A. B., Glebov V.V. et al. Improving the quality of gas-thermal

coatings by heat treatment with high-frequency currents and a laser beam // Welding Production № 6, 2004. P.43-46.

16. Sokolov Yu.V., Sadova M.A., Popok, D.A. Heat treatment of sprayed coatings / Vest. Belarus tech. inst. № 3, 2004. - P. 40-41 
17. Improving the quality of gas-thermal coatings from wire materials by means of chemical heat treatment / P.A. Vitiaz, R.O. Azizov, M.A. Belotserkovsky, V.A. Kukareko // Friction and wear. - Vol. 24, No. 6. 2003. - P. 666-672.

18. Belotserkovsky M.A. Hardening by chemical heat treatment of coatings obtained by fast spraying steel wires / M.A. Belotserkovsky, V.M. Konstantinov, G.A. Tkachenko // Surface Engineering, Welding: Proc. Int. Symp., Minsk, 2009. P. 178-184.

19. 33. Priadko A.S., Dudan A.V., Brusilo Yu.V., et al. Choice of equipment for hardening and restoring automotive transport parts by arc spraying. Polotsk, Bull. of Polotsk State University. 3, 2014, P. 121-126.

20. 34. Brusilo Yu.V. Choice of equipment for hardening and restoring parts of piston engines by arc spraying. J. "Aerospace Engineering and Technology" Kharkiv. No. 4 (71), 2010. P. 38-42.

21. 35. Karp I.N., Petrov S.V., Rudoi A.P. Installation for arc metallization in a supersonic flow of natural gas combustion products // Welding Production, 2, 1991. P. 22-23.

22. 36. Device for fast spraying (versions) / Belotserkovsky M.A, Priadko A.S., Cherepko A.E. // Patent of Belarus No. 4365, Publ. 03/30/2002.

23. Pokhmursky V.I. Protective and restorative electric metallization of coatings from cored wires // V.I. Pokhmursky, M.M. Student, V.S. Pikh // New processes and equipment for gas-thermal and vacuum coating: Coll. of papers "Electric welding"- Kyiv, 1990. P. 66 - 69.

24. Student M.M. Development of old and new electrometallic coatings to cover powder darts: Thesis. Lviv, 1998 - 18 p.

25. Ageev M.S. Restoration of ship pump shafts using a combined method of applying protective coatings / Ageev M.S., Kozhevnikova E.E, Lopata V.N. // Science Bulletin KhDMA - Kherson: 2015, No. 2 (13). - P. 416.

26. Buriakin A.V., Kuzmin A.V. Electric arc metallization with metal spraying by combustion products of hydrocarbon fuels // Welding Production, 3, 1993. P. 7-9.

27.. Belotserkovsky M.A. Structural anomalies in steel gas-thermal coatings and the possibility of their use / M.A. Belotserkovsky // Strengthening Technologies and Coatings, 10, 2008. P. 39-44.

28. Vitiaz P.A, Belotserkovsky M.A., Kukareko V.A., et al. Structure and properties of coatings from steel 40Kh1 produced using various methods for gas-thermal spraying // Physical mezomechanika.-, V.5, No. 1. 2002 P. 15-22.

29. 40. Potekhin B.A., Lobanov M.N., Nasedkina E.M. Influence of unstable austenitic structure of steel 9Kh18 on cavitation and abrasive resistance // Phys.-chemical mechanics of materials, , 2. 1976. P. 116-118. 
Агеев М. С., Солових Е.К., Лопата В. Н., Бурлаченко А.Н., Вигилянская Н.В. Дослідження факторів процесу напилення на властивості електродугових покриттів

В роботі запропоновано підвищувати зносостійкість, корозійну стійкість і термін служби деталей машин і механізмів при їх відновленні і зміцненні ЕДН-покриттями з високою щільністю, міцністю зчеплення і мікротвердістю за рахунок керування параметрами процесу напилення та його активацією.

В роботі розглянута можливість за рахунок вибору конструктивних параметрів і характеристик обладнання для ЕДН керувати властивостями відновлених поверхонь 3 метою підвищення ресурсу деталей машин. Правильний вибір конструкції обладнання для напилення дозволить збільшити швидкість і температуру струменя транспортуємих газу і частинок, зменшити діаметр крапель, підвищити щільність і знизити окислюваність покриттів. В роботі виконані дослідження впливу чинників процесу електродугового напилення: витрати і тиску робочих газів, складу горючої суміші, дистанції напилювання, дисперсності розпилення, властивостей матеріалу дроту і ін.

Ключові слова: покриття, отримані електродуговим напиленням, процес напилення, зносостійкість, корозійна стійкість, міцність зчеплення, щільність 